ORIGINAL ARTICLE

\title{
Histopathological span of diseases in patients going through hysterectomies: an audit of 190 consecutive hysterectomy specimens in Multan
}

\author{
ZERTAJ KASHIF ${ }^{1}$, SONIA ZAFAR WARRIACH ${ }^{2}$, SEHAR SHAMSHAD ALI ${ }^{3}$, MUHAMMAD BILAL PASHA ${ }^{4}$, KANWAR SAJID \\ $\mathrm{ALI}^{5}$, AYESHA KASHIF6, AAMIR ALI KHAN ${ }^{7}$ \\ ${ }^{1}$ Associate Professor Pathology, Bakhtawar Amin Medical \& Dental College, Multan \\ ${ }^{2}$ FCPS Obstetrics and Gynaecology, DHQ Jhang \\ ${ }^{3}$ Senior Demonstrator, Bakhtawar Amin Medical \& Dental College, Multan \\ ${ }^{4}$ Assistant Professor Pathology, Bakhtawar Amin Medical \& Dental College, Multan \\ ${ }^{5}$ Associate Professor, Bakhtawar Amin Medical \& Dental College, Multan \\ ${ }^{6} 4^{\text {th }}$ Year Trainee FCPS (II), Community Medicine, Nishter Medical University Multan \\ ${ }^{7}$ Professor of Pathology, Bakhtawar Amin Medical \& Dental College, Multan \\ Correspondence to: Dr. Zertaj Kashif, Email: zkashif786@icloud.com, Cell: 03146121201
}

\begin{abstract}
Introduction: Gynecological diseases affect women's lives in numerous manners. They are frequent in all communities but the types of disorders and their presentations differ substantially in various regions and races. However, the studies and researches specifying these disorders in particular regions and communities are very low in number.

Hysterectomy is one of the most frequently opted operations worldwide particularly in developing countries and hardly any studies are done about its epidemiology and prevalence in Multan region of Pakistan.

Objective: The objective of this study is to assess the variety of histopathological diseases in patients undergoing hysterectomies in Multan region

Design: Retrospective study including 190 hysterectomy specimens.

Place and duration: Department of Histopathology Bakhtawar Amin Medical \& Dental College, Multan from January 2019 to December 2020.

Methodology: Histopathology reports of all hysterectomy specimens removed due to gynecological disorders were included. All the relevant data like age, parity, clinical manifestations, indication and type of hysterectomy were recorded along with histopathological microscopic diagnosis of cervix, endometrium, myometrium, fallopian tubes and ovaries. The data was collected from medical track record, histopathological request form and histopathology report files.

Results: A total of 190 hysterectomies were received in histopathology department. The mean age was 47.8 years (ranging from 25-75 years). Majority of the ladies were between age groups 41-50 years. The major presenting complaint was menstrual irregularity followed by abdominal pain. Out of 190 specimen, 170 (89.5\%) of hysterectomies were done because of non neoplastic/ benign conditions. Chronic cervicitis, adenomyosis and leiomyomata were the most commonly noticed incidental findings.

Conclusion: Hysterectomy is an extensively used therapeutic modality, largely for benign non neoplastic disorders to relieve the clinical symptoms and to enhance the living conditions. Presence of incidental diseases in majority of hysterectomy specimens indicates that for conclusive opinion, histopathological examination is must.

Key words: Histopathology, hysterectomy, benign gynecological disorders, leiomyoma, adenomyosis
\end{abstract}

\section{INTRODUCTION}

Gynecological disorders are one of the common problems encountered in clinical practice where large number of women visit clinical practitioners to seek help; and a major bulk of these disorders are benign in nature. ${ }^{1,26}$

These disorders are largely ignored in many low resources settings all over the world especially in Pakistan. Insufficient knowledge and understanding of the health issues and lack of medical services often lead to late diagnosis, resulting in greater morbidity, more chances of uterine removal and increase in mortality as well. ${ }^{3}$

Hysterectomy is an operation to remove the uterus. All around the world this surgery is performed in large numbers. $^{4}$

Received on 05-01-2021

Accepted on 02-06-2021
Abdominal hysterectomy is the routinely opted surgical technique for benign disorders in Pakistan. ${ }^{5}$

The chance of hysterectomy in the course of women's life ranges from $30-40 \%$ as it is the ultimate solution for numerous benign and malignant gynecological disorders. ${ }^{6}$

The gynecological problems are universal in occurrence but there is hardly any absolute data and statistics available regarding prevalence and occurrence of various gynecological diseases in Pakistan except few studies conducted in certain large cities. According to a study conducted in Karachi, out of 100, 41 women faced gynecological problems. ${ }^{7}$

The most common gynecological disorders encountered in women of Pakistan are however, ovarian cysts, irregular periods, fibroid uterus, polycystic ovarian disease, infections and cervical cancer. ${ }^{8}$

The objective of this study was to ascertain the spectrum of histopathological diagnoses encountered in women undergoing hysterectomy procedures. 


\section{MATERIAL AND METHODS}

This descriptive study was conducted at Bakhtawar Amin Hospital, Multan over a period of 3 years from January 2018 to December 2020. Histopathology reports of all hysterectomy specimen were included. Obstetrical hysterectomies were excluded in this study. Data like age, parity, presenting complaints and indication for hysterectomy and type of hysterectomy were recorded. Percentage and proportions were calculated for all the variables. Relevant tables and charts were computed.

\section{RESULTS}

During the last two years, a total of 190 hysterectomies were received in the histopathology laboratory. The mean age was 47.8 years (ranging from $25-75$ years). Majority of the patients were between age group 41-50 years.

The major presenting complaint was menstrual irregularity followed by pain abdomen.

Table 1: Types of Hysterectomies

\begin{tabular}{|l|l|l|}
\hline Type of Hysterectomy & $\begin{array}{l}\text { Number of cases } \\
(\mathrm{n}=190)\end{array}$ & $\begin{array}{l}\text { Percentage } \\
(\%)\end{array}$ \\
\hline Vaginal Hysterectomies & 12 & 6.3 \\
\hline $\begin{array}{l}\text { TAH without fallopian tubes \& } \\
\text { ovaries }\end{array}$ & 104 & 54.7 \\
\hline $\begin{array}{l}\text { TAH with bilateral salpingo- } \\
\text { oophorectomy (BSO) }\end{array}$ & 52 & 27.4 \\
\hline $\begin{array}{l}\text { TAH with unilateral salpingo- } \\
\text { oophorectomy (USO) }\end{array}$ & 14 & 7.4 \\
\hline Subtotal (only uterus) & 8 & 4.2 \\
\hline Total & 190 & 100 \\
\hline
\end{tabular}

Table 2: Main Presenting Complaint

\begin{tabular}{|l|l|l|}
\hline Major mode of presentation & $\begin{array}{l}\text { Frequency } \\
(\mathrm{n}=254)\end{array}$ & $\begin{array}{l}\text { Percentage } \\
(\%)\end{array}$ \\
\hline Abdominopelvic pain & 62 & 24.4 \\
\hline $\begin{array}{l}\text { Bleeding per } \\
\text { vaginum/menstrual } \\
\text { disturbances }\end{array}$ & 159 & 62.6 \\
\hline Cervical discharge & 21 & 8.3 \\
\hline Uterovaginal prolapse & 12 & 4.7 \\
\hline
\end{tabular}

Table 3: Distribution of cases according to Age

\begin{tabular}{|l|l|l|}
\hline Age Group (Years) & Number of cases & Percentage (\%) \\
\hline $20-30$ & 12 & 6.3 \\
\hline $31-40$ & 48 & 25.3 \\
\hline $41-50$ & 78 & 41.1 \\
\hline $51-60$ & 40 & 21.1 \\
\hline $61-70$ & 6 & 3.1 \\
\hline$>70$ & 6 & 3.1 \\
\hline
\end{tabular}

Table 4: Distribution of cases according to Parity

\begin{tabular}{|l|l|l|}
\hline Parity & Number of cases & Percentage (\%) \\
\hline Nulliparous & 02 & 1.1 \\
\hline 1 & 06 & 3.1 \\
\hline 2 & 14 & 7.4 \\
\hline 3 & 67 & 35.3 \\
\hline 4 and more & 101 & 53.1 \\
\hline
\end{tabular}

Out of 190 hysterectomy specimen, 170 (89.5\%) were non neoplastic (benign), and 20 (10.5\%) were malignant. Among 170 benign lesions, the commonest histopathological finding encountered was chronic cervicitis (176 cases). It was an incidental finding in nearly all cases.
Other less common benign lesions were leiomyomata and adenomyosis.

Out of 190 hysterectomies, 20 (10.5\%) patients had gynecological malignancies and squamous cell carcinoma of the cervix appeared to be the most frequently detected malignancy noticed in (8/20) $40 \%$ of all malignant lesions.

Table 5: Histopathological diagnosis of Cervical Lesions

\begin{tabular}{|l|l|l|}
\hline Histopathological diagnosis & $\begin{array}{l}\text { Number of } \\
\text { cases } \\
(\mathrm{n}=259)\end{array}$ & $\begin{array}{l}\text { Percentage } \\
(\%)\end{array}$ \\
\hline Acute Cervicitis & 02 & 0.8 \\
\hline Chronic Cervicitis & 159 & 61.4 \\
\hline Papillary Cervicitis & 42 & 16.2 \\
\hline Squamous metaplasia & 34 & 13.1 \\
\hline Microglandular hyperplasia & 02 & 0.8 \\
\hline Cervical Polyp & 01 & 0.4 \\
\hline Cevical Leiomyoma & 03 & 1.1 \\
\hline Cervical squamous cell carcinoma & 08 & 3.1 \\
\hline Cervical adenocarcinoma & 04 & 1.5 \\
\hline Adenocarcinoma in situ & 01 & 0.4 \\
\hline $\begin{array}{l}\text { Cervical intraepithelial neoplasia } \\
\text { (CIN I) }\end{array}$ & 01 & 0.4 \\
\hline $\begin{array}{l}\text { Cervical intraepithelial neoplasia } \\
\text { (CIN III) }\end{array}$ & 02 & 0.8 \\
\hline
\end{tabular}

Table 6: Histopathological diagnosis of Endometrial Lesions

\begin{tabular}{|l|l|l|}
\hline Histopathological Diagnosis & $\begin{array}{l}\text { Number of } \\
\text { cases } \\
(\mathrm{n}=205)\end{array}$ & Percentage \\
\hline PHASE OF ENDOMETRIUM & & \\
\hline Proliferative endometrium & 95 & 46.3 \\
\hline Secretory endometrium & 06 & 2.9 \\
\hline Atrophic endometrium & 12 & 5.9 \\
\hline Disordered endometrium & 39 & 19.0 \\
\hline ENDOMETRIAL HYPERPLASIA & & \\
\hline Simple hyperplasia without atypia & 24 & 11.7 \\
\hline Complex hyperplasia & 02 & 1.0 \\
\hline $\begin{array}{l}\text { Pseudodecidual reaction in the } \\
\text { stroma }\end{array}$ & 10 & 4.9 \\
\hline Endometritis & 05 & 2.4 \\
\hline Benign endometrial polyp & 07 & 3.4 \\
\hline Endometrial Carcinoma & 02 & 1.0 \\
\hline Malignant mixed mullerian tumor & 03 & 1.5 \\
\hline
\end{tabular}

Table 7: Histopathological diagnosis of Myometrial Lesions

\begin{tabular}{|l|l|l|}
\hline Histopathological Diagnosis & $\begin{array}{l}\text { Number of cases } \\
(\mathrm{n}=212)\end{array}$ & $\begin{array}{l}\text { Percentage } \\
(\%)\end{array}$ \\
\hline Leiomyoma & 71 & 33.5 \\
\hline Adenomyosis & 82 & 38.7 \\
\hline Normal Histology & 59 & 27.8 \\
\hline
\end{tabular}

Table 8: Histopathological diagnosis of Fallopian tube Lesions

\begin{tabular}{|l|l|l|}
\hline Histopathological Diagnosis & $\begin{array}{l}\text { Number of cases } \\
(\mathrm{n}=118)\end{array}$ & $\begin{array}{l}\text { Percentage } \\
(\%)\end{array}$ \\
\hline Normal & 109 & 92.4 \\
\hline Endometriosis & 06 & 5.1 \\
\hline Paratubal cysts & 03 & 2.5 \\
\hline
\end{tabular}

Table 8: Histopathological diagnosis of Ovarian Lesions

\begin{tabular}{|l|l|l|}
\hline Histopathological Diagnosis & $\begin{array}{l}\text { Number of } \\
\text { cases } \\
(\mathrm{n}=119)\end{array}$ & $\begin{array}{l}\text { Percentage } \\
(\%)\end{array}$ \\
\hline No significant pathology & 103 & 86.6 \\
\hline Follicular cyst & 05 & 4.2 \\
\hline Corpus luteal cyst & 02 & 1.7 \\
\hline Endometriosis & 06 & 5.0 \\
\hline Benign Mucinous cystadenoma & 01 & 0.8 \\
\hline Benign serous cystadenoma & 02 & 1.7 \\
\hline
\end{tabular}


Table 9: Distribution of all the malignant lesions

\begin{tabular}{|l|l|l|}
\hline Malignant lesion & $\begin{array}{l}\text { Number of } \\
\text { cases } \\
(\mathrm{n}=20)\end{array}$ & $\begin{array}{l}\text { Percentage } \\
(\%)\end{array}$ \\
\hline CERVIX & 08 & \\
\hline $\begin{array}{l}\text { Cervical squamous cell } \\
\text { carcinoma }\end{array}$ & 04 & 40 \\
\hline Cervical adenocarcinoma & 01 & 20 \\
\hline Adenocarcinoma in situ & 02 & 05 \\
\hline $\begin{array}{l}\text { Cervical intraepithelial } \\
\text { neoplasia (CIN III) }\end{array}$ & 02 & 10 \\
\hline ENDOMETRIUM & 03 & 10 \\
\hline Endometrial adenocarcinoma & 02 & 15 \\
\hline $\begin{array}{l}\text { Malignant mixed mullerian } \\
\text { tumor }\end{array}$ & 03 & \\
\hline
\end{tabular}

\section{DISCUSSION}

Hysterectomy is the most commonly executed significant gynecological operation all over the world. It helps in providing immediate absolute relief in many benign and malignant conditions of uterus, cervix and adnexae. (9)

Today hysterectomy is a routine procedure opted globally, offering the chances of cure to many patients; however the figures of this surgical operation have been declined remarkably in developed countries due to switch towards conservative approaches. Still the numbers are higher than the developing countries. (10)

The mean age of women who underwent hysterectomy due to gynecological disorders in our study was 47.8 years in accordance with several studies conducted in Pakistan and abroad where the mean ages found were 48.8 years 46.86 years, $45.76 y e a r s, 45$ years, 43 years and 40.37 years respectively. $(2,11,12,13,14$, 15)

Most $(78 / 190) 41.1 \%$ of these women were between ages 41 to 50 years, comparable to the studies conducted by Shahid R, Egbe TO and Imam ZS. $(15,13,16)$

Irregular excessive bleeding and pain were the most frequent presenting complaints in our study. Similar mode of presentations was seen in several other studies. $(15,17)$

Most women presented with single manifestation; however many others complaint of overlapping symptoms.

The overall occurrence of non neoplastic benign lesions in this study was $170 / 190(89.5 \%)$ as compared to $20 / 190(10.5 \%)$ malignant neoplastic lesions. These findings are supported by several local studies (5, 14, and 15) as well as studies from India, China and Michigan. (2, $12,18)$

The commonest non neoplastic benign lesion in this study was chronic cervicitis which is an incidental finding in nearly all cases. This is consistent with several studies in which chronic cervicitis appeared to be the commonest incidental finding in cervix. $(9,16,19)$

However, leiomyomas and adenomyosis were the most frequent myometrial histopathological lesions and indication for hysterectomy in our study, in keeping with several other studies. $(11,20,21)$

The most common type of hysterectomy was TAH without tubes and ovaries in our study. This is in accordance with several other studies where number of total abdominal hysterectomy was much more than vaginal hysterectomies. $(5,22,23)$
Endometriosis was another incidental finding observed in $6 \%$ of cases in both fallopian tubes and ovaries; this incidence is quite close to several other studies. $(15,24,25)$

\section{CONCLUSION}

Hysterectomy is an extensively used therapeutic modality. The conclusive opinion is eventually made on histopathological examination. Non neoplastic benign pathologies are much more frequent reasons for hysterectomy than the malignant lesions and majority of these lesions especially chronic cervicitis, adenomyosis and even few leiomyomas are encountered as incidental findings along with endometriosis and few ovarian cysts.

Limitations: In this region of the world most ladies don't consult doctors especially for gynecological issues until and unless there is marked health related disturbance; especially single unmarried and young ladies with low parity as it is considered a social taboo; due to such delay even mild non neoplastic benign conditions get worse and hysterectomy remains the last option.

Secondly most people here lack health positive attitudes and don't go for expensive thorough investigations that lead to missed preoperative diagnosis and increased number of incidental findings on histopathology.

\section{REFERENCES}

1. Black KI, Fraser IS. The burden of health associated with benign gynecological disorders in low-resource settings. International Journal of Gynecology \& Obstetrics. 2012 Oct;119:S72-5.

2. Liu F, Pan Y, Liang Y, Zhang C, Deng Q, Li X, Liu M, He Z, Liu Y, Li J, Ning T. The epidemiological profile of hysterectomy in rural Chinese women: a population-based study. BMJ open. 2017 Jun 1;7(6).

3. Awan NJ, Khan A. Prevalence of Gynecological Morbidities among Reproductive Age Women in Bhudni Village, Peshawar-Pakistan. Pakistan Journal of Medical Research. 2017 Oct 1;56(4).

4. Saffarieh E, Ahmadi R, Pazoki R, Yousefnezhd A, YousefiSharami R. The study of life expectancy in hysterectomized women in Semnan Amir Al Momenin Hospital in 2017. Journal of family medicine and primary care. 2020 Feb;9(2):826.

5. Shaikh AG, Shaikh SN. Abdominal Hysterectomy For Benign Diseases. Journal of Surgery Pakistan (International). 2018 Jul;23:3.

6. Perveen SA, Ansari AS, Naheed FU, Sultana A. Pattern of lesion in hysterectomy specimens and clinical correlation. PJMHS. 2014;8:465-8.

7. Ayub M, Awan M, Zaidi NF, Feroze WQ, Tauseef $Y$. Knowledge and barriers towards prevalence of Gynecological problems among females of Karachi: A Cross sectional Study. 2016 Nov- Dec RJLBPCS 2(4) Page 69-77

8. Umair I. 5 Common Gynecological Issues Faced by Women in Pakistan. 2017

9. Mishra A, Mishra P, Brig. N. K, Pandey T, Srivastava S, Dwivedi M. Histopathological spectrum of hysterectomy specimens and its correlation with clinical diagnosis at a tertiary care centre. Trop J Path Micro 2019;5(4): 240- 247

10. Hammer A, Rositch AF, Kahlert J, Gravitt PE, Blaakaer J, Søgaard M. Global epidemiology of hysterectomy: possible impact on gynecological cancer rates. American journal of obstetrics and gynecology. $2015 \mathrm{Jul}$ 1;213(1):23-9.

11. Michael D, Mremi A, Swai P, Shayo BC, Mchome B. Gynecological hysterectomy in Northern Tanzania: a cross- 
sectional study on the outcomes and correlation between clinical and histological diagnoses. BMC Women's Health. 2020 Dec;20(1):1-8.

12. Mahnert N, Morgan D, Campbell D, Johnston C, As-Sanie S. Unexpected gynecologic malignancy diagnosed after hysterectomy performed for benign indications. Obstetrics \& Gynecology. 2015 Feb 1;125(2):397-405.

13. Egbe TO, Kobenge FM, Arlette MM, Eta-Nkongho E, Nyemb JE. Prevalence and Outcome of Hysterectomy at the Douala General Hospital, Cameroon: A Cross-Sectional Study. Int J Surg Res Pract. 2018;5:092.

14. Majeed TA, Adnan RA, Mahmood ZA, Mahmood H. Audit of Gynaecological Hysterectomies. Pak J Med Health Sci. 2013;7(3):684-7.

15. Shahid R, Abbas H, Mumtaz S, Perveen F, Bari MF, Raja T, Memon S, Ahmed N, Dawani K. Hysterectomy and Oophorectomy in Reproductive Age: A Cross-Sectional Study from a Tertiary Care Hospital. Cureus. 2020 May;12(5)

16. Imam ZS, Chandra K, Kumar B, Sinha A, Singh A, Singh SK. HISTOPATHOLOGICAL SPECTRUM OF HYSTERECTOMY SPECIMENS--A RETROSPECTIVE ANALYSIS AT IGIMS, PATNA, BIHAR. Journal of Evolution of Medical and Dental Sciences. 2018 Jul 23;7(30):3352-6.

17. Desai S, Shukla A, Nambiar D, Ved R. Patterns of hysterectomy in India: a national and state-level analysis of the fourth national family health survey (2015-2016). BJOG: An International Journal of Obstetrics \& Gynaecology. 2019 Aug;126:72-80.

18. Shekhar C, Paswan B, Singh A. Prevalence, sociodemographic determinants and self-reported reasons for hysterectomy in India. Reproductive health. 2019 Dec;16(1):1-6.

19. Medhi P, Dowerah S, Borgohain D. A histopathological audit of hysterectomy: experience at a tertiary care teaching hospital. International J of Contemporary Medical Research. 2016;3(4):1226-8.

20. Naheed K, Hussain A, Ali R. Clinico-Pathological Study of Hysterectomy at Pak Red Crescent Medical and Dental College. J Islamic Int Med Coll. 2018;13(2):62-5.

21. Nyirahabimana D, Musoni E, Mbarushimana D, Rugwizangoga B. Analysis of Histopathological Lesions in Hysterectomy Specimens at Two Teaching Hospitals in Rwanda : A Two Year Review. J Gynecol Infertility. 2018;1(1):1-4.

22. Dolon MF. A Critical Review of 100 Cases of Hysterectomy: A Prospective Study in a Tertiary Care Centre. Sch Int J Obstet Gynec. 2021;4(2):44-8.

23. Zargar AA, Tasleem RA, Dar FS, Reshi R, Ali N, Sayeed SI, Wani HA. Profile of Hysterectomy Specimens: Prospective Clinco-Pathological Study. Int J Med Res Prof.2018 Mar; 4(2); 301-07

24. Boyd CA, Riall TS. Unexpected gynecological findings during abdominal surgery. Current problems in surgery. 2012 Apr;49(4):195.

25. Ahsan S, Naeem S, Ahsan A. A case notes analysis of hysterectomy performed for non-neoplastic indications at Liaquat National Hospital, Karachi. Journal-Pakistan Medical Association. 2001 Oct 1;51(10):346-8.

26. Zafar S, Mahmood G, Haq AN. Burden of gynaecological disease in a tertiary hospital: two years audit of outpatient department at PIMS. JOURNAL-PAKISTAN MEDICAL ASSOCIATION. 2004 Oct 1;54(10):513-5. 